\title{
INJECTION OF OILY SOLUTION OF IODIN FOR GLAUCOMA.
}

\author{
Ricilaru Kerry, M.D.,
}

MUNTREAL, CANADA.

Five cases are here reported in which this new procedure was used with apparently very good results. The author had previously employed it successfully in iritis.

The similarity in the acute symptoms of septic iritis and glaucoma, if one cxcepts the purely mechanical effects in the latter discase; and the fact that pain in iritis is so promptly relieved by iodin, have led the writer to tuse this drug in some recent cases uf glaucoma. The results have proved most interesting, and it scems probable that further experience will demonstrate that we have in iodin a very valuable adjunct to the measures at present employed in treating this discase. In the following cases the relief from pain and abatement of symptoms Were very prompt and marked.

Case 1. A woman of forty odd years. I.eft cye absolute glaucoma, right seriously impaired, was trephined some years ago with good result. Three ycars later she came with an acute attack, complaining of pain and loss of vision. 'The cye was hard, showing ciliary injection and cloudy media, apparently more from round cell infiltration than edema. She was given an injection of iodin, arol all signs and symp- toms disappeared promptly, only to return again in two weeks in greater severity. Another injection was given and the cxtraction of some roots from the jaw ordered. The symptoms disappeared as before, and did not recur at the time. Two years or so later another attack came on, while the writer was absent from the city, an iridectomy was done with unfortunate result and the sight lost.

Casi: 2. Woman forty years. Had subacute glatucoma for a momth with the classical signs and symptoms; after some preliminary treatment, she was given iodin, and shortly afterwards consulted another oculist who denicd the diagnosis. As both my comfrere and mysclf are capable of diagnosing glatucoma with the usual signs, it is evident that the symptoms had disap. jeared before the comsultant saw the ase.
Case 3. Woman 35 years old. Had acute glatucoma in both cy (s, the symptoms were severe and the inability to use the rye distressing. Vision $6 / 36$ to 6,24. She was given iodin once a weck for a month, and was then able to use lier eyes quite comfortably, vision having returned to normal. Jextensive gingivitis was treated and later two alveolat absecsses were evacuated. but the ante symptoms had disappeared before the teeth lad been at tended to. Reeent reports nearly a year later, do not indicate any recurrence.

Case 4. Man 60 ycars old. Right eye hald iridectomy done, a woek before the writer was asked to see the casse, owing to the left cye having become affected. The patient was suffering severely, and was not relicred by the morphin which had been given. He was sent to hospital, for operation next morning, and was given ioclin. Ifo passed a comfortable night and in the moming the eye was practically painless. $\AA$ trephine operation wats dome and there was no complaint of pain afterwards and but little reaction from the operation, vision in the left "ye becoming normal in a fow wecks time. Eserin was prescribed by the pationt's physician during the last attack, and four days after the acute $s: m$ : : m; had subsided the condition was as follows:

Right cye sensitive, molerate com. gestion to nasal side, anterior chanber very shallow, pupil half dilated, immobile; apparently displaced upward owing to retraction being yreater above than below. At eight o'clock were onc or two pigment spots, one of which was within the pupil. The fundus was somewhat congested, no depression of dises, no gross change in the ficlds, tension not raised, vision $6 / 6$ with + 6.5. J. 1. with + 10, better with + 11 .

This case would secmingly corre. spond to Parker's type of glaticoma in- 
volving the posterior lymphatics (A. J. O. v. 2, p. 628), but the presence of recent posterior synechiae and a dilated immobile pupil suggests both glaucoma and iritis. Examination three days after iodin had been given showed disappearance of subjective symptoms and of the congestion. The pupil was still immobile, but displacement was not quite so great. Three days after the second dose there was active contraction of the lower part of the pupil on stimulation by light, the upper part being still immobile, with an angle in the margin at eleven o'clock, due to dilatation limited to this one point. A week later the pupil was nearly in norinal position, somewhat oval in shape, grcatest dilatation at eleven o'clock (but no angular kink as previously). From about ten to two o'clock it was still immobile. The eyeball was still soft and there were no subjective symptoms present.

Eserin causes only moderate contraction of the pupil, the paralysed section remaining inactive. But since the margin as a whole has contracted the condition is evidently not duc to hidden synechiae.

This interesting symptom-complex exhibits in an unusual manner that most constant symptom of all forms of glaucoma, interference with the motor function in the eye, and was associated at its onset with an abscess inside the right check; there are no teeth or roots in the jaws. When seen recently, some three months after the onset of the attack, the pupil was normal in appearance and action.

Case 5. Woman aged 60 . Has had several attacks of severe pain in the right eye luring the past few months; when examined ncarly a year ago no pathologic condition was found, vision with plus $7=\mathrm{R}$. 6/5 I. Amblyopic.

The writer's experienco with iodin in iritis has convineed him that it is not unreasonable to attribute to the drug the unustal effects olutained in these cases, and while sivereping cont clusions are not justified by such limited evidence there are one or two practical points suggested ly these results which are worth considering in connection with glaucoma.

Iodin acts by stimulating leucocytic activity to a marked degree and thus tends to disperse inflammatory foci. So powerful indeed is its action in this respect that in the presence of gross lesions, such for instance as pulmonary carity, acute toxemia is induced, which may end fatally.

Schmabcl's observation that artificially induced arterial pulsation in the cycball is accompanicd by emptying of the voins and paling of the rlisc, while in rlatcoma pulsation coexists with venous engorgement and a congested lisc, is conclusive cvidence of interfurence with the venous outflow from the eyeball.

The many pathologic reports published, showing alteration in the veins with blocking of both veins and lymphatics by round cells and debris fur uish further evidence of this interfercuce, which, by causing hypertension in the eycball, compresses the outlet of the reins still more, thus establishing a vicious circle.

If now, we can by stimulating leucocytosis restore the circulation and remove the causes of stasis, and this appars to have occurred in the cases reported, we shall have practical proof of the importance of the vascular fac. tor in causing glallcoma.

It would thus secm that the chemical and physical changes tupon which Fisclier lays stress are secondary to, mather than a cause of circulatory disturbance. These cases indicate also that the vascular change is lue to sepsis, but further work is required to establish the role of the infective angent both in glaucoma and iritis, more cipecially in chronic glaucoma in which evidence of stasis is lacking.

Jn practise, the relief from pain fol lowing the use of ioclin in inflammatory alses amd the fact llat its employment in comjunction with follin's operation minimizes postoperative reaction, and any remeleney to clominge wi the tre phine openimg by axudite, strongly favers the aloption of this simple pro colure, which in no way contraindi cates ordinary methods. 
If we can lepend upon obtaining resulls such as those given abover, we shall, in doubtiul cascs, cause arrest of the discase and disappearance of the symptoms, even while we are arguing about the diagnosis. While in severe cases iodin will enlance the result of cperation and afford great relief to the pationt.

Ten to fifteen minims of a onc in forty solution of iodin in Sesame oil, was injected once a weck under the skin with a hypodermic syringe. Jutging from the strength and dose of sevcral preparations on the market, the dose used in these cases can be increased considerably without harm resulting, possibly with bencfit. Massive dosage in scysis is recommended by the mwners of our proprictary preparation. Failing Sesane oil which is at present difficult to obtain, almond or almost any biand fixed ail can be substituted.

When is glaucoma not glatuoma? The paraphrase is certainly suggested by these cases, which, altho differing in type arc obviously all related. It is far more practical in a given case, to re- nove disease than to demonstrate that it belongs to establisherl type, and should be labelled accordingly. The facts above recorded indicate the direction in which we may reasonably look for further progress in treating this often intractable discase, and the case of a well known statesman whose loss of sight is stated to be due to alveolar ibscess adds point to this obscrvation.

\title{
THE ORGANIZATION AND ACTIVITIES OF THE OPHTHALMIC SERVICE IN THE AMERICAN ARMY OF OCCUPATION
}

\author{
RALPII A. FENTON, M.D., \\ PORTLAND, OREGON.
}

This is a supplement to the paper of Col. Grcenwood published last year, A. J. O., v. 2, p. 565., Major Fenton having been ophthalmic consultant for the Arny of Occupation. The two papers constitute an authoritative history of the ophthalmic service in the American Expeditionary Forces. Anthority to publish granted, Board of Publication, S. G. O.

Suggestions from Colonel Black to Colonel Greenwood regarding eye service in the Army of Occupation, as published in Col. Greenwood's report (A.J.O. v. 2, p. 583), were necessarily modified by direction of the Chicf Surgeon, Colonel J. W. Grissinger, M. C., to meet conditions found on arrival in Ciermany. The atsignment of a combined ophthalmologrist and otolaryngologist to each division, with use of a field hospital in cach division for milel eye cases, was never done becalise of lack of personnel and equipment, as well as accessibility of cracuation hospitals to divisional areas. The other suggestions, of centers for eyc work in 'Treves and Coblenz, with auxiliary uptical units for supply of glasses. wore fully carried out; and the Chief surgeon was ready at all times to farilitite in every wiy the elaboration of clinical cquipmont and the provision of highly gualified persommel. Colonel
Black's valuable counsel was available from Juxemburg on into Coblenz, during Decomber, 1918, and again for a few days at the end of January, 1919.

During the American advance from ligny-en-Barrois, November, 1918, thru the devastated region above Verlun and across Luxcmburg, there was little special work, except for occasional cases of injury to children and other civilians from abandoned German grenades or other munitions. Sev(ral cases of this type were seen in a ficld hospital at i.ongwy, and were turned over to French atuthorities as the troops moved forward. Other civil cases, left by the Germans practically without medical supplies, were in charge of Frencl sisters in a convent lospital at I onguyon, the first field headquarters. Supplies were furnished them and an army hospital worked with them for a time. While headquaters were here and at I uxemburg. 